\title{
Making Early Positive Impact on Freshmen through Engineering Technology Seminars
}

Dr. Maher M Murad, University of Pittsburgh, Johnstown

Dr. Maher Murad is an associate professor in the Civil Engineering Technology department at the University of Pittsburgh at Johnstown. Dr. Murad served as a visiting professor at Bucknell University. He also has overseas teaching and professional experience. He worked as a technical manager at Modern Contracting and as a highway project manager at Acer Freeman Fox International. He is a licensed professional engineer (P.E.) in the state of Ohio. Dr. Murad received a Masters degree in Civil Engineering and a Ph.D. in Engineering Science from the University of Toledo. 


\title{
Making Early Positive Impact on Freshmen Through Engineering Technology Seminars
}

\begin{abstract}
Freshmen admitted to the engineering technology (ET) program at the University of Pittsburgh at Johnstown (UPJ) are required to take a noncredit ET seminar. Freshmen meet weekly for one hour with an ET senior instructor. The seminar instructor implements a variety of activities throughout the semester aimed at positively influencing the attitudes and habits of freshmen in order to better prepare them for the demands of the ET program as well as their own lives. The activities allow students to self-examine themselves and have a better feel for what it takes to succeed in the ET program and in life in general.

To better understand the influence of the seminar on freshmen students, a survey at the end of the semester asked the freshmen class to recall the lessons learned from the ET seminar about "themselves," "succeeding in the ET program," and "life in general." Numerous freshmen students have emphasized the significant influence this ET seminar and its instructor had on their attitudes, habits, and other aspects of their lives. The ET seminar weekly activities and the results of the survey are summarized and presented. The paper provides ideas for engineering technology programs looking for ways to have significant early positive impact on their freshmen students that lasts beyond their college years.
\end{abstract}

\section{Introduction}

ET programs offer a variety of entry level courses aimed at preparing freshmen students for the challenges they are expected to face in their college years and perhaps beyond. Such courses may or may not be offered for a credit. Many of these course are developed to satisfy the Criteria for Accrediting Engineering Technology Programs ${ }^{1,}$ especially Criterion 3: Students Outcomes (h, I, $\mathrm{j}$ and $\mathrm{k}$ ) that state:

h. an understanding of the need for and an ability to engage in self-directed continuing professional development;

i. an understanding of and a commitment to address professional and ethical responsibilities including a respect for diversity;

j. a knowledge of the impact of engineering technology solutions in a societal and global context; and

k. a commitment to quality, timeliness, and continuous improvement.

Examples of these courses and their objectives are as follows:

- A team-taught ET Freshmen Experience course to educate students on the importance of ethical decision making, the importance of courses they will be taking, and how they will impact them later in the program, as well as in life. ${ }^{2}$ In this course, students work in teams and communicate orally and in writing.

- Freshmen courses to help students deal with failure and make the transition between high school and college. ${ }^{3}$ 
- A freshmen seminar course to address other ABET Criterion 3 outcomes in the freshman year, particularly global and societal context (h), contemporary issues (j), and lifelong learning (i). ${ }^{4}$ The free elective involves guest speakers and team projects.

- A year long course covering freshmen survival skills. Topics include learning styles and teaching styles, leadership opportunities, how to take college exams, how to work in teams, time management skills, dealing with personal conflicts, and resources on campus. ${ }^{5}$

At UPJ, a senior ET faculty member developed this seminar in which he meets weekly with the entire freshmen class to discuss topics related to three major areas: understanding oneself, keys to success in ET studies, and life beyond college years. The seminar instructor gets other ET faculty involved along with selected UPJ organizations such as the Academic Success Center. The seminar uses the textbook "Studying Engineering Technology: A Blueprint for Success" 6 but relies heavily on the experience and leadership of the instructor and the presentations of the different faculty and UPJ personnel.

A variety of topics are covered as outlined below:

- Academic integrity, student conduct, and ethics.

- Academic success strategies: structuring college life, effective use of professors and peers, diversity, and academic advising.

- Personal growth and development: receptiveness to change, behavior modification, understanding self and others, communication skills, mental/physical wellness and personal motivation.

- Study skills: goal setting, time management, test anxiety, problem solving, selfmanagement, and decision making.

- The ET profession and the ET majors: the engineering profession (what is engineering? rewards/opportunities, disciplines, job functions, and professional registration).

- The benefits of participating in the different ET student organizations.

For example, on the topic of setting and achieving goals, the freshmen set goals, assess their progress, and hold themselves and their team members accountable. The process teaches students some of the fundamentals of project management such as setting specific, realistic, and measurable goals. In this exercise, students work in teams consisting of three students. It begins with a simple statement of personal academic aspiration of each student for the semester. Students are given the freedom to write any scholastic goal that they have. The process of formulating and writing a goal often is a benefit in and of itself. The student will be far more aware of it. The specific goal itself is not important to the process. The goals will vary per individual; one student may be striving to achieve a 4.0 GPA while another may set a goal of simply passing a difficult course. ${ }^{7}$

Instruction then follows on what constitutes a valid and authentic goal and how it must be articulated in the form of the following specific elements: realistic, specific, measurable, written, and completion date. The students are instructed that a goal is realistic if it is achievable within the time frame allotted. The elements of specific and measurable goals require the most interaction from the professors. Once the students rewrite their aspirations so they conform to an 
authentic goal, it is advisable that the seminar professors review the students' rewritten goals and offer comments on their measurability prior to moving on to the next step. The final goals are presented to the other team members who scrutinize and validate each goal, again ensuring that they contain the four specific elements: realistic, specific, measurable and written, and completion date.

Each team member signs an "Academic Resolution Worksheet" authenticating his or her input and the process of accountability commences. Goal accountability is the responsibility of the team members. Each team sits together at the weekly freshman seminar. The first ten minutes of class are devoted to each team member discussing the progress or lack of it they made on each goal during the previous week. Students assign a "percentage" to each goal indicative of how thoroughly they performed the goal for the week. ${ }^{7}$ Table 1 list the course outcomes.

Table 1: Course Outcomes

\section{Course Outcomes}

1. Students be able to identify many of the engineering technology faculty members and their particular engineering technology discipline

2. Students should be able to describe the majors available in engineering technology at UPJ

3. Students should be able to identify the various engineering technology student organizations and the benefits of membership and involvement

4. Students should be able to identify the keys to success in college and engineering technology study

5. Students should be able to describe and implement time management and organizational skills

6. Students should be able to describe studying and test taking strategies for success in college

7. Students should be able to express awareness of critical thinking skills and discuss their use in specific engineering and social applications

8. Students should be able to identify ways to implement self-improvement and behavior modification to facilitate personal growth and development

9. Students should be able to establish goals and set priorities.

10. Students should be able to identify and discuss skills used in problem solving and decision making

11. Students should be able to describe and use various library resources for scholarly activities

12. Students should have developed an understanding of ABET/TAC and its role in their engineering technology education 


\section{ET Freshmen Survey}

A questionnaire was administered at the end of the term to solicit opinions from the freshmen class about the lessons learned in this course with respect to three areas: 1- Myself, 2-Succeeding in my undergraduate studies, and 3- Life in general. Sixty two (62) freshmen students participated in the survey.

Table 2 summarizes the responses of the students on how this seminar influenced them personally. The comments in Table 2 indicate that most freshmen students have a better understanding of themselves with respect to attitude, level of involvement, determination, and confidence. Students appear to have a better understanding of what they are missing and what they need to do to overcome that. Their positive tone indicates that the seminar has positively affected their attitude and confidence. "Believing in yourself" and "being the best you can be" were the most repeated comments by students.

Table 2: Most important lesson I learned about myself

\begin{tabular}{|l|}
\hline \multicolumn{1}{|c|}{ Myself } \\
\hline How to market yourself \\
\hline I am my own limiting factor \\
\hline I must push myself to achieve my goals \\
\hline It is possible and I can do it... I have what it takes (repeated) \\
\hline I have a duty and the potential to be great \\
\hline I need to focus (repeated) \\
\hline To apply myself to more ways than just the classroom \\
\hline I should try to be the best I can be (repeated) \\
\hline I can achieve anything I want to if I try hard enough (repeated) \\
\hline I am not as involved as I should be \\
\hline If I do my best then I won't have any regrets \\
\hline I am not as motivated as I should be \\
\hline I am not as goal oriented as I should be \\
\hline I have to offer more to get hired over the rest \\
\hline I am a slacker \\
\hline Be the best version of yourself that you can be (repeated) \\
\hline I need to treat things more seriously \\
\hline I need to get involved in more activities and stay determined (repeated) \\
\hline Always have a positive attitude \\
\hline I am capable of being a successful engineer \\
\hline My decisions now affect my future career \\
\hline I can be a leader \\
\hline Engineering is for me and I am no longer second guessing myself \\
\hline I am truly the only person who controls my future \\
\hline
\end{tabular}


Table 3 summarizes the responses of the students on the most important lesson they learned about succeeding as undergraduates in ET. The comments in Table 3 indicate that most freshmen students have a better understanding of what it takes to succeed in engineering technology. Hard work, focus, balancing work and other activities, getting involved in extracurricular activities, and determination have been the most repeated comments from students to guarantee success in studying and pursuing a career in engineering technology.

Table 3: Most important lesson I learned about succeeding in undergraduate studies

\begin{tabular}{|l|}
\multicolumn{1}{|c|}{ Succeeding in My Undergraduate Studies } \\
\hline I need to standout in the crowd by doing more (repeated) \\
\hline I need to focus and work hard (repeated) \\
\hline I need to work in clubs as well as class \\
\hline Business before pleasure \\
\hline It takes a lot of work to succeed \\
\hline It's not all about the grade \\
\hline Hard work and dedication pay off (repeated) \\
\hline I will succeed if I work towards my career goal \\
\hline Manage my time correctly and have my priorities straight \\
\hline It is OK if I am not a 4.0 student \\
\hline To study harder, use common sense, get involved, and try your best (repeated) \\
\hline You can help or hurt no body but yourself \\
\hline Importance of studying and staying focused (repeated) \\
\hline Study, study, and study \\
\hline Employers look for more than grades and looks (repeated) \\
\hline Be more involved because that is one of the things employers look for \\
\hline Go the extra step \\
\hline I have a long way to go \\
\hline Participate in other activities (repeated) \\
\hline With hard work anything can be accomplished \\
\hline Learn to work with other students because you will be working with other engineers in future \\
\hline It is important to balance study, habits and times to relax (repeated) \\
\hline Success or failure is all up to me. If I want something I can get it (repeated) \\
\hline I learned not to procrastinate \\
\hline Work hard to make something of myself because other people are trying to take my job \\
\hline
\end{tabular}

Table 4 summarizes the responses of the students on the most important lesson they learned about life in general. The comments in Table 4 indicate that most freshmen students have learned some lessons about life and professional success. Being enthusiastic, motivated, and competitive are repeated thoughts by students. Being the best you can be is one comment students have listed under all categories. 
Table 4: Most important lesson I learned about life in general

\begin{tabular}{|l|}
\hline \multicolumn{1}{|c|}{ Life in General } \\
\hline Live life to the fullest (repeated) \\
\hline Peruse the things you like \\
\hline Time management is important (repeated) \\
\hline People are cruel \\
\hline Have fun accomplishing things \\
\hline I am in control of my own ship \\
\hline Extracurricular activities will help me stand out (repeated) \\
\hline Never give up \\
\hline Must show enthusiasm \\
\hline Relax and enjoy school and don't worry so much \\
\hline Life isn't handed to you, you have to work for what you want \\
\hline There is competition in the real world so work hard and convince employers to pick you \\
\hline Don't stand back but go after what you want \\
\hline If you want to succeed you have to want it \\
\hline You have to be motivated if you have to go any where \\
\hline Life will kick you but you have to get back up \\
\hline Be competitive (repeated) \\
\hline My job doesn't have to be boring \\
\hline Don't be lazy \\
\hline If it's stupid but it works, it isn't stupid! \\
\hline Even if it is not broke, make it better \\
\hline Good things will come in time \\
\hline Never sell yourself short \\
\hline Find what makes you happy in life \\
\hline Be the best you can be and go the extra mile (repeated) \\
\hline
\end{tabular}

The success of this seminar over the years has been linked to the senior instructor of the course. Another survey was conducted to solicit opinions on the instructor from graduates of the ET program to assess his influence on graduates of the ET program through the seminar. ${ }^{8}$ Thirty one (31) former students have emphasized the significantly positive influence this instructor has had on not only their careers, but also in other aspects of their lives.

The survey took an open format and asked the ET gradates to express their opinions of this instructor in terms of the qualities they felt he possessed and how he influenced their careers/lives. The qualities of this instructor from the survey can be categorized in two groups: teaching qualities and personal qualities. Tables 5 and 6 list a summary of the qualities indicated in the student survey. 
Table 5: Teaching qualities of the instructor identified by former students

\begin{tabular}{|l|}
\hline \multicolumn{1}{|c|}{ Teaching Qualities } \\
\hline Challenging but fair \\
\hline Captivating teaching style \\
\hline $\begin{array}{l}\text { Discussed world issues (current events) in class that were important to students as persons } \\
\text { and as engineers }\end{array}$ \\
\hline Very disciplined - ran his classes firm, fair and respectfully \\
\hline Had full command of the material and really wanted students to learn \\
\hline Effectively combined textbook theory and examples with real applications \\
\hline Interaction with students - unique and positive \\
\hline Using groups/teams - taught students how to cooperate \\
\hline $\begin{array}{l}\text { Taught every class with a positive view and treated each student with same respect and } \\
\text { individuality }\end{array}$ \\
\hline He possesses highly motivated thinking \\
\hline Always interested that students understood material before moving on \\
\hline $\begin{array}{l}\text { Teaching presentations - you could not help but be attentive and interested in what was being } \\
\text { presented }\end{array}$ \\
\hline $\begin{array}{l}\text { Teaching could convey underlying principles of a subject and also instill a practical sense of } \\
\text { its application }\end{array}$ \\
\hline $\begin{array}{l}\text { Cared about not only how material was presented, but how the students received and } \\
\text { understood that information }\end{array}$ \\
\hline Teaching based on a "real life approach" \\
\hline
\end{tabular}

Table 6: Personal qualities of the instructor identified by former students

\begin{tabular}{|c|}
\hline Personal Qualities \\
\hline Genuine interest in students \\
\hline Uses words of encouragement. He encouraged each and every one of his students \\
\hline Not too proud to admit mistakes \\
\hline Leads by example \\
\hline Had both technical and personal influence \\
\hline $\begin{array}{l}\text { Taught students: } \\
\text { - Have concern for others } \\
\text { - Ethics both in engineering and in general } \\
\text { - Respect for self } \\
\text { - Discipline }\end{array}$ \\
\hline $\begin{array}{l}\text { Took time to advise students in trouble, giving advice and direction to help students get } \\
\text { back on track - Available for personal advice }\end{array}$ \\
\hline Stressed importance for people to take responsibility for their actions \\
\hline Very intelligent and disciplined individual, but also fair minded and approachable \\
\hline $\begin{array}{l}\text { Mentor to his students and he took great pride in his work and the development of his } \\
\text { students }\end{array}$ \\
\hline Never ending enthusiasm \\
\hline Provided a great deal of guidance and encouragement \\
\hline
\end{tabular}


The survey also included other comments that relate to qualities of this instructor and his influence on their careers/lives:

- Students respect instructor for knowing he cares about their future

- Students remember his advice (catch phrases)

$\circ$ Don't sweat the small stuff, and it's all small stuff 9

- Choose a job you love and you will never work another day in your life

- Someone will handle the crisis, so why not you

- Much of the advice and encouragement he conveyed helped formulate many of the decisions I've made throughout my lifetime. His efforts as a teacher have made a permanent imprint on my life

- He let us know, through his support, that we were capable of becoming competent engineers, regardless of gender

- Instilled the belief that if we thought we were capable of success, then success was attainable

- I admire his leadership and organizational skills, and compassion for students

- Always concerned with students on a personal level, as well as on a professor/student level

- One of most caring individuals encountered in my career

- Teaching and learning based on "your own personal initiative

- Acts as a "coach", encouraging students to work in teams and not always relying on the professor for answers

- Gets students to realize that if they don't speak up when they have a problem, then the only person they can blame is themselves

- No hand-holding, students must work hard to understand material and result is they retain information better

- Excellent interaction with students - always felt comfortable going to him if there was a problem

- Provided students with many required skills and a positive attitude towards life

- Asked students to look deep into their own character and to evaluate their personal and leadership characteristics

It appears that the instructor's approach to teaching this seminar has been consistent with Lowman's research and other studies ${ }^{10,11}$. Such studies identified a "two-dimensional model" of good teaching. The first and the most important is intellectual excitement, which includes organization and clarity of presentation of up-to-date material. The second dimension identified is interpersonal rapport. This includes showing interest in students as individuals, encouraging them to think independently, and being warm, open, predictable, and student-oriented.

\section{Conclusions}

Most freshmen ET students at UPJ have emphasized a positive influence this ET seminar and its instructor had on their attitudes, habits, and other aspects of their lives. Freshmen students indicated they have a better understanding of themselves with respect to attitude, level of involvement, determination, and confidence. Their positive tone indicates that the seminar has positively affected their attitude and confidence. "Believing in yourself" and "being the best you 
can be" were the most repeated comments by students. They appear to have a feel for what it takes to succeed in engineering technology. Hard work, focus, balancing work and other activities, getting involved in extracurricular activities, and determination have been the most repeated comments from students to guarantee success in studying and pursuing a career in engineering technology. Students in this seminar have learned some lessons about life and professional success as well. Being enthusiastic, motivated, and competitive are repeated thoughts by students. Graduates of the ET program identified a number of teaching and personal qualities of the seminar instructor. An instructor could only be viewed as excellent by his/her students if he/she teaches effectively with passion and if he/she genuinely shows a personal compassion for students.

\section{Bibliography}

1. Accreditation Board for Engineering and Technology (ABET), "Criteria for Accrediting Engineering Technology Programs: Effective for Evaluations During the 2016-2017 Accreditation Cycle," Baltimore, MD. , October 2015

2. Dobrowski T., "Proposed Freshmen Experience Course." Proceedings of the American Society for Engineering Education Annual Conference \& Exposition, Louisville, Kentucky, June 2010.

3. Budny D., Allen A., Tartt J, "Dealing With Failure and Making the Transition between High School and College." Proceedings of the American Society for Engineering Education Annual Conference \& Exposition, Louisville, Kentucky, June 2010.

4. Jenkins M. and Yates L., "Development and Assessment of a Freshman Seminar to Address Societal Context" Proceedings of the American Society for Engineering Education Annual Conference \& Exposition, Portland, Oregon, June 2005.

5. Blowers P.., "A Course on Freshman Survival Skills" Proceedings of the American Society for Engineering Education Annual Conference \& Exposition, Montreal, Canada, June 2002.

6. Cheshier, S. "Studying Engineering Technology: A Blueprint for Success." Discovery Press, 1998.

7. Miller A., Martinazzi R., and Murad M., "The Alchemy of Helping Freshmen Turn Dreams into Reality." Proceedings of the American Society for Engineering Education Annual Conference \& Exposition, Salt Lake City, Utah, 2004.

8. Murad M., Rose A., "Short and Long-term Influence of Excellent Instructors on Graduates in Engineering Technology: a Case Study." Proceedings of the American Society for Engineering Education Annual Conference \& Exposition, Chicago, Illinois, June 2006.

9. Carlson. R. Don't Sweat the Small Stuff, and It's All Small Stuff, HYPERION, New York, 1997.

10. Lowman. J. Mastering the Techniques of Teaching, Jossey-Bass, San Francisco, CA, 1985.

11. Mehta S, and Danielson J. "The Scholarship of Teaching: Building a Foundation before Reaching the Pinnacle." Proceedings of the American Society for Engineering Education Annual Conference \& Exposition, Albuquerque, New Mexico, 2001. 